\title{
Haplotype structure enables prioritization of common markers and candidate genes in autism spectrum disorder
}

\author{
BN Vardarajan ${ }^{1,2}$, A Eran ${ }^{3,4}$, J-Y Jung ${ }^{1}$, LM Kunkel ${ }^{4}$ and DP Wall ${ }^{1}$
}

Autism spectrum disorder (ASD) is a neurodevelopmental condition that results in behavioral, social and communication impairments. ASD has a substantial genetic component, with 88-95\% trait concordance among monozygotic twins. Efforts to elucidate the causes of ASD have uncovered hundreds of susceptibility loci and candidate genes. However, owing to its polygenic nature and clinical heterogeneity, only a few of these markers represent clear targets for further analyses. In the present study, we used the linkage structure associated with published genetic markers of ASD to simultaneously improve candidate gene detection while providing a means of prioritizing markers of common genetic variation in ASD. We first mined the literature for linkage and association studies of single-nucleotide polymorphisms, copy-number variations and multi-allelic markers in Autism Genetic Resource Exchange (AGRE) families. From markers that reached genome-wide significance, we calculated male-specific genetic distances, in light of the observed strong male bias in ASD. Four of 67 autism-implicated regions, 3p26.1, 3p26.3, 3q25-27 and 5p15, were enriched with differentially expressed genes in blood and brain from individuals with ASD. Of 30 genes differentially expressed across multiple expression data sets, 21 were within $10 \mathrm{cM}$ of an autismimplicated locus. Among them, CNTN4, CADPS2, SUMF1, SLC9A9, NTRK3 have been previously implicated in autism, whereas others have been implicated in neurological disorders comorbid with ASD. This work leverages the rich multimodal genomic information collected on AGRE families to present an efficient integrative strategy for prioritizing autism candidates and improving our understanding of the relationships among the vast collection of past genetic studies.

Translational Psychiatry (2013) 3, e262; doi:10.1038/tp.2013.38; published online 28 May 2013

\section{Introduction}

Autism spectrum disorder (ASD) is a neurodevelopmental condition that results in behavioral, social and communication impairments. It is currently estimated that 1 in every 88 children in the United States is affected with ASD, with boys five times more likely to be affected than girls. ${ }^{1}$ ASD has a substantial genetic component, ${ }^{2-4}$ with $88-95 \%$ monozygotic twin concordance and an estimated heritability of $60-90 \%{ }^{5}$ A recent study showed that a large proportion of the variance in liability among monozygotic twins can be explained by shared environmental factors (55\% for autism and $58 \%$ for ASD) in addition to moderate genetic heritability (37\% for autism and $38 \%$ for ASD). ${ }^{6}$ Studies conclude that there are multiple genetic factors that have a role in the etiology of autism. Recent findings have provided evidence in support of roles for de novo mutations, ${ }^{7-10}$ common genetic variants, ${ }^{11}$ rare variants ${ }^{12}$ and copy-number variation. ${ }^{13-15}$ Nevertheless, the genetic basis of the majority of ASD remains largely unclear.

Contributing to the complexity, ASD linkage studies have uncovered over 70 susceptibility loci across the genome and a large number of gene candidates, ${ }^{16,17}$ but most of these findings have not been successfully replicated. The only exceptions to this trend have been linkage peaks on
$17 q 11-17 q 21^{18-21}$ and $7 q .^{22-26}$ Yet, linkage and association studies have dominated the approaches to disentangle the genetic etiology of autism for more than two decades, leaving behind a rich legacy of research findings in the biomedical literature. Reports of significant linkage peaks represent an important clue to the genetic cause of autism that should not be ignored, even in the absence of sufficient replication. Aside from the possibility of false positives, absence of replication could be due to several factors such as lack of sample size, differential recombination rates in the replication population, lower coverage in the replication samples of genetic markers in the linkage peaks or batch effects. However, the mechanistic relevance of the marker should still be determined. For example, a marker may designate collections of genes involved in biological processes or individual genes with mutations of high importance to the susceptibility to autism. Furthermore, these markers and their importance to the etiology of autism, once they have achieved the minimum significance threshold of logarithm-of-the-odds of 3.0 or an association $P$-value of $<0.05$ (corrected for multiple testing), are usually treated as equal. Therefore, despite the fact that markers provide maps, the granularity of those maps is insufficient to direct prioritized experimental follow-up, as every marker, and every gene proximal to that marker, is

${ }^{1}$ Center for Biomedical Informatics, Harvard Medical School, Boston, MA, USA; ${ }^{2}$ Gertrude H. Sergievsky Center, Columbia University, New York, NY, USA; ${ }^{3}$ HarvardMIT Health Sciences and Technology, Cambridge, MA, USA and ${ }^{4}$ Division of Genetics, Program in Genomics, Boston Children's Hospital, Boston, MA, USA

Correspondence: Dr D Wall, Center for Biomedical Informatics, Harvard Medical School, 10 Shattuck Street, Boston, MA 02115, USA.

E-mail: dpwall@ @ms.harvard.edu

Keywords: AGRE; autism genetics; autism spectrum disorders; bibliome mining

Received 10 Decemeber 2012; revised 13 March 2013; accepted 21 April 2013 
equally likely to be as important. Given that markers have been identified on nearly every chromosome, the utility of linkage studies for providing specific gene leads and directing further experimental research is limited.

In the present study, we have focused on maximizing the value of previously published linkage and association findings using families from the Autism Genetic Resource Exchange (AGRE) project for directing further genetic analysis of autism. Specifically, our aim was to provide finer resolution to published linkage and association studies through a novel analytical strategy focused on marker-to-gene male-specific genetic distance. Our study was loosely predicated on the assumption that genes in tight linkage with a susceptibility locus are more likely to be linked with the phenotype of interest, that is, autism, and was leveraged by the collective understanding that the disorder has a substantial male bias. As such, our work focused on reconstructing the male-specific structure of linkage disequilibrium (LD) surrounding significant autism markers to sets of genes in tight, medium and distant LD with those markers. We examined the biological signal inherent to each concept and measured its expression in peripheral blood and postmortem brain tissue from individuals with autism as compared with controls. This strategy improves the resolution of marker-based findings by pointing to the specific genes contributing to the linkage and/or association signals, more likely to have a role in ASD. A large percentage of these genes had not been previously linked to autism but had been implicated in numerous other neurological diseases, including those with overlapping symptoms. Given the ability of this strategy to identify important and novel signal among the rich collection of research findings from various linkage and association studies in autism, we anticipate that it will have broader applications in the study of other complex genetic disorders in which a large collection of samples had been previously typed and not immediately available for modern sequencing.

\section{Materials and methods}

Autism marker selection. We first mined the autism literature to identify genetic studies focusing on AGRE families. Owing to the focus on AGRE families, all probands included here were assessed and diagnosed using the same instruments and procedures. We identified 67 reports of significant autism linkage and association signals spanning 18 chromosomes (Table 1). Significance thresholds were a logarithm-of-the-odds score $>3$, which is suggestive evidence of linkage or corrected-association $P$-value $<0.01$ (depending on the number of markers tested in the study). The search was restricted to studies performed on AGRE families because the same subjects were used to calculate the genetic map around autism markers. This strategy allowed us to capture the true rates of recombination in the studied population and avoid any potential recombination bias. As the linkage and association studies were based on various experimental designs, we developed the strategy described below to enable their meta-analysis.

Each marker was first mapped to the NCBI human genome build 36.3. Then, a $20-\mathrm{Mb}$ slice flanking that genomic coordinate was retrieved and the single-nucleotide polymorphisms (SNPs) within that region were used for calculating a genetic map using the same subjects' genotypes. ${ }^{11}$ The nearest SNP to the autism marker was used as the reference for calculating recombination rates with other SNPs. The recombination rates were determined with respect to the reference. We assumed that the recombination rates between the marker and the nearest SNP was negligible, enabling us to designate that SNP as a proxy for the marker. Owing to the heterogeneity in the discovery methods of the various regions (linkage vs association, copy-number variations vs SNPs and so on), we treated each region as equally significant. This enabled us to use an unbiased approach in finding genes and regions that were enriched for autism cases.

Calculation of LD structure of autism markers. In order to establish the male-specific LD structure between genes and autism markers, we created genetic maps from a 20-Mb slice of the chromosome flanking each linkage locus. Specifically, we collected and assembled SNPs $10 \mathrm{Mb}$ upstream and $10 \mathrm{Mb}$ downstream of each autism marker using the SNP data for AGRE probands. ${ }^{11}$ As autism is almost five times more prevalent in males, we filtered out the females from the data set before calculating the genetic map. These filtration procedures followed the logic that an AGRE data specific and male-only genetic map would be the most likely to provide an accurate reflection of the samples contributing to the linkage and association signals reported in the pooled studies.

To create the genetic maps for each autism marker, we estimated fine-scale recombination rates using the LDhat software package. ${ }^{27}$ This program estimates recombination rates between adjacent SNPs by fitting a Bayesian model based on coalescent theory to analyze patterns of LD in the data. We conducted this analysis for all 67 markers, identifying the male-specific genetic distances between the marker and genes surrounding that marker, measured in $\mathrm{cM}$. For further filtering, we pruned the genetic map to $15 \mathrm{cM}$ around the marker. A process flow for the creation of these LD structure (LDS) sets is depicted in Figure 1.

Messenger RNA expression data processing. Gene Expression Omnibus data sets GSE6575 28 and GSE2852 $11^{29}$ were used to examine the expression of genes surrounding significant autism markers in individuals with ASD. The GSE6575 data set consists of 17 samples of individuals with ASD without regression, 18 individuals with ASD with regression, 9 patients with mental retardation or developmental delay, and 12 typically developing children from the general population. In this previous study, total RNA was extracted from whole blood samples using the PaxGene (Qiagen, Germantown, MD, USA) Blood RNA System and run on Affymetrix U133plus2.0 (Santa Clara, CA, USA). For the purposes of our study, we elected to use the 35 individuals with autism and 12 control samples from the general population. Preprocessing and expression analyses were done with the Bioinformatics Toolbox Version 2.6 (for Matlab R2007a +, Mathworks, Natick, MA, USA). GeneChip Robust Multi-array Average was used for background adjustment, and control probe intensities were used to estimate nonspecific binding. ${ }^{30}$ Housekeeping genes, gene 
Table 1 Autism markers identified in AGRE families between 2001 and 2012

\begin{tabular}{|c|c|c|c|c|c|}
\hline Chromosome & Marker & $\begin{array}{l}\text { Median marker } \\
\text { position (bp) }\end{array}$ & $\begin{array}{c}\text { Male-specific } \\
\text { genetic map } \\
\text { units (cMs) }\end{array}$ & $\begin{array}{l}\mathrm{P} \text {-value/LOD } \\
\text { (association/linkage) }\end{array}$ & References \\
\hline 1 & dup RFWD2-PAPPA2 & 174522115 & 23.3 & $P=1.0 \mathrm{e}-02$ & 37 \\
\hline 1 & rs12740310-rs3737296-rs12410279 & 218873645 & 26.7 & $P=5.0 \mathrm{e}-04$ & 38 \\
\hline 1 & D1S1656 & 228971975 & 40.9 & $\mathrm{NPL}=3.21$ & 39 \\
\hline 1 & rs6683048 & 235855409 & 37.6 & $P=2.3 e-09$ & 40 \\
\hline 2 & dup AK123120 & 13142782 & 41.5 & $P=3.57 \mathrm{e}-06$ & 37 \\
\hline 2 & del NRXN1 & 50557085 & 20.9 & $P=3.30 \mathrm{e}-04$ & 41 \\
\hline 2 & del NRXN1 & 51134122 & 21.7 & $P=4.7 \mathrm{e}-04$ & 37 \\
\hline 2 & rs17420138 & 158585159 & 19.6 & $P=5.63 \mathrm{e}-08$ & 40 \\
\hline 2 & rs1807984 & 168787136 & 22.9 & $P=7.0 \mathrm{e}-03$ & 42 \\
\hline 2 & D2S335 & 172274852 & 22.8 & $\begin{array}{l}\mathrm{HLOD}=2.99 \\
\mathrm{NPL}=3.32\end{array}$ & 43 \\
\hline 2 & rs4519482 & 172671605 & 24.2 & $P=7.0 \mathrm{e}-05$ & 44 \\
\hline 2 & $204,444,539-204,446,116$ LD block & 204445327 & 26.6 & $P=1.8 \mathrm{e}-06$ & 45 \\
\hline 3 & del CNTN4 & 1915556 & 27.0 & $P=4.7 \mathrm{e}-04$ & 37 \\
\hline 3 & del UNQ3037 & 4218017 & 30.4 & $P=2.0 \mathrm{e}-03$ & 37 \\
\hline 3 & D3S3045-D3S1763 & 138597603 & 23.2 & $\begin{array}{l}\mathrm{Z}=3.10 \\
P<1.0 \mathrm{e}-03\end{array}$ & 18 \\
\hline 3 & dup NLGN1 & 174763176 & 21.5 & $P=1.0 \mathrm{e}-02$ & 37 \\
\hline 4 & rs17599165 & 46634972 & 18.1 & $P=1.5 \mathrm{e}-03$ & 46 \\
\hline 4 & rs1912960 & 46648638 & 18.8 & $P=7.3 \mathrm{e}-03$ & 46 \\
\hline 4 & rs17599416 & 46668195 & 19.1 & $P=4.0 \mathrm{e}-03$ & 46 \\
\hline 4 & rs6826933-rs17088473 & 61133187 & 17.8 & $\begin{array}{l}\mathrm{HLOD}=3.79 \\
\mathrm{LOD}=2.96\end{array}$ & 47 \\
\hline 4 & dup GUSBP5 & 144850990 & 22.8 & $P=1 \mathrm{e}-02$ & 37 \\
\hline 5 & rs10513025 & 9676622 & 38.4 & $P=1.7 \mathrm{e}-06$ & 48 \\
\hline 5 & rs1896731-rs10038113 & 25936438 & 29.3 & $P=3.4 \mathrm{e}-06$ & 38 \\
\hline 5 & rs4307059 & 26003460 & 31.6 & $P=3.0 \mathrm{E} 4 \mathrm{e}-08$ & 11 \\
\hline 5 & rs11959298-rs6596189 & 134395753 & 23.2 & $P=4.0 \mathrm{e}-04$ & 49 \\
\hline 6 & rs13193457 & 15453984 & 35.0 & $P=3.0 \mathrm{e}-05$ & 50 \\
\hline 6 & del PARK2 & 162585788 & 31.6 & $P=4.7 \mathrm{e}-03$ & 37 \\
\hline 7 & rs 736707 & 102917639 & 21.8 & $P=1.40 e-5$ & 51 \\
\hline 7 & rs1858830 & 116099675 & 17.0 & $P=5.0 \mathrm{e}-06$ & 52 \\
\hline 7 & rs38841 & 116107162 & 16.0 & $P=6.0 \mathrm{e}-04$ & 53 \\
\hline 7 & rs7794745 & 146120539 & 36.7 & $\begin{array}{l}\mathrm{LOD}=3.4 \\
P<2.14 \mathrm{e}-05\end{array}$ & 54 \\
\hline 7 & rs2710102 & 147205323 & 35.0 & $P=2.0 \mathrm{e}-03$ & 55 \\
\hline 7 & D7S483 & 151829212 & 33.4 & $\mathrm{NPL}=3.7, P=7.9 \mathrm{e}-05$ & 56 \\
\hline 7 & rs1861972-rs1861973 & 154946830 & 28.1 & $P=3.5 \mathrm{e}-06$ & 57 \\
\hline 9 & rs1340513 & 6967633 & 35.7 & $\begin{array}{l}\mathrm{Zlr}=3.21 \\
P=7.0 \mathrm{e}-04\end{array}$ & 58 \\
\hline 9 & rs722628 & 7136888 & 35.7 & $\begin{array}{l}\mathrm{Zlr}=3.59 \\
P=6.0 \mathrm{e}-03\end{array}$ & 58 \\
\hline 9 & rs536861 & 127353265 & 31.6 & $\begin{array}{l}\mathrm{Zlr}=3.30 \\
P=5.0 \mathrm{e}-04\end{array}$ & 58 \\
\hline 10 & del GRID1 & 87945347 & 30.8 & $P=3.1 \mathrm{e}-04$ & 37 \\
\hline 11 & rs2421826 & 35187181 & 24.5 & $\mathrm{ZIr}=3.57$ & 58 \\
\hline 11 & rs1358054 & 36163248 & 25.6 & $\begin{array}{l}\mathrm{Zl} r=3.77 \\
P=8.0 \mathrm{e}-03\end{array}$ & 58 \\
\hline 11 & rs6590109 & 124264258 & 37.7 & $P=9.0 \mathrm{e}-03$ & 59 \\
\hline 12 & rs1445442 & 63577561 & 25.0 & $\mathrm{HLOD}=4.51$ & 60 \\
\hline 14 & del MDGA2 & 46796374 & 22.1 & $P=1.3 \mathrm{e}-04$ & 41 \\
\hline 15 & del OR4M2,OR4N & 19844860 & 26.1 & $P=9.48 \mathrm{e}-12$ & 41 \\
\hline 15 & del LOC650137 & 19915407 & 24.8 & $P=9.48 \mathrm{e}-12$ & 41 \\
\hline 15 & dup UBE2A & 23184355 & 38.4 & $P=9.27 \mathrm{e}-06$ & 41 \\
\hline 15 & dup $15 q 11-13$ & 23704547 & 37.5 & $P=1.0 \mathrm{e}-05$ & 37 \\
\hline 15 & maternal dup $15 q 11-13$ & 23750000 & 36.1 & p approaching 0 & 61 \\
\hline 15 & GABRB3 155CA-2 & 24559869 & 38.2 & MTDT $P=2.0 \mathrm{e}-03$ & 62 \\
\hline 15 & rs25409 & 24569934 & 39.2 & $P=8.0 \mathrm{e}-03$ & 63 \\
\hline 15 & dup $15 q 13$ BP4-BP5 & 29508500 & 42.5 & p approaching 0 & 64 \\
\hline 15 & rs11855650-rs10520676 & 77364734 & 23.0 & $\begin{array}{l}\mathrm{HLOD}=3.09 \\
\mathrm{LOD}=3.62\end{array}$ & 47 \\
\hline 16 & FE0DBACA18ZG03v & 19408579 & 32.6 & $P=1.6 \mathrm{e}-04$ & 65 \\
\hline 16 & FE0DBACA7ZD06v & 24133057 & 26.8 & $P=1.4 \mathrm{e}-05$ & 65 \\
\hline 16 & $\mathrm{del} / \mathrm{dup} 16 \mathrm{p} 11.2$ & 30300000 & 45.5 & $P=1.1 \mathrm{e}-04$ & 61,66 \\
\hline 17 & D17S1294-D17S1800 & 26183756 & 22.2 & $\begin{array}{l}\text { HLODREC }=5.8 \\
P=1.59 \mathrm{e}-07\end{array}$ & 67 \\
\hline 17 & D17S1294 & 26860299 & 20.9 & $\begin{array}{l}\text { MLS }=3.2 \\
\text { Male-only } \mathrm{MLS}=4.3\end{array}$ & 68 \\
\hline 17 & D17S1299 & 36247989 & 25.7 & $\mathrm{MLS}=3.6$ & 19 \\
\hline 17 & D17S2180 & 44028199 & 24.7 & $\mathrm{MLS}=4.1$ & 19 \\
\hline 17 & rs757415 and rs12603112 & 46020488 & 22.8 & $P=1.9 \mathrm{e}-05$ & 69 \\
\hline 17 & del BZRAP1 & 53747037 & 29.0 & $P=8.0 \mathrm{e}-04$ & 41 \\
\hline 19 & del MADCAM1 & 451915 & 17.8 & $P=6.0 \mathrm{e}-04$ & 41 \\
\hline 19 & rs344781 & 48866628 & 23.9 & $P=6.0 \mathrm{e}-03$ & 70 \\
\hline 20 & rs723477 & 237362 & 22.8 & NPL LOD $=3.81$ & 48 \\
\hline 20 & rs16999397-rs200888 & 958294 & 24.5 & $\begin{array}{l}\mathrm{HLOD}=3.36 \\
\mathrm{LOD}=3.38\end{array}$ & 47 \\
\hline 20 & rs4141463 & 14695471 & 34.8 & $P=3.7 \mathrm{e}-08$ & 71 \\
\hline 21 & D21S1437 & 20568713 & 28.4 & $\begin{array}{l}\mathrm{NPL}=3.4 \\
P=3.5 \mathrm{e}-04\end{array}$ & 56 \\
\hline
\end{tabular}

Abbreviations: AGRE, Autism Genetic Resource Exchange; SNP, single-nucleotide polymorphism.

Linkage and association studies performed in AGRE families were compiled and genome-wide significant markers identified. The logarithm-of-the-odds (LOD) scores and/or association $P$-values are listed for each marker. Human genome build 36.3 was used to calibrate marker position. Male-specific genetic distances were calculated using dense SNP genotypes from the same individuals. 


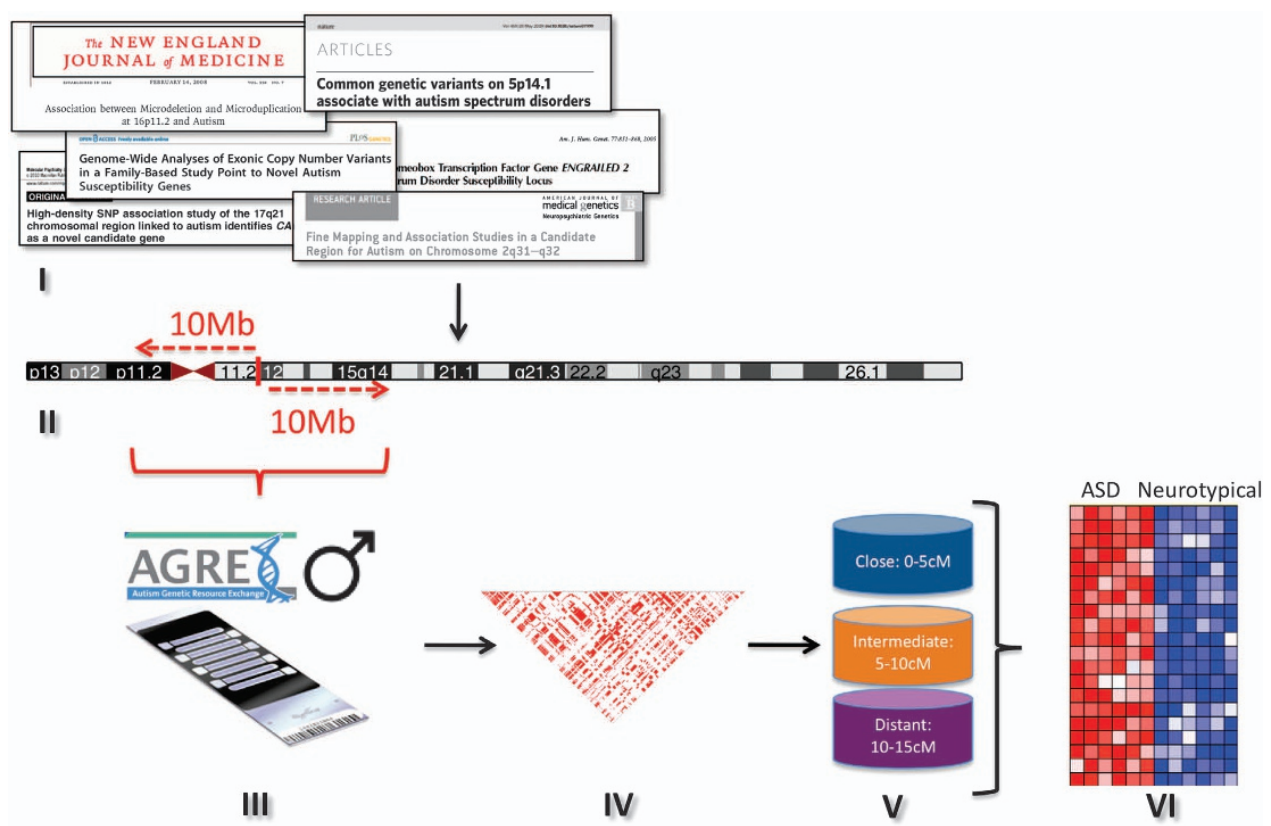

Figure 1 Integrative genomics workflow for prioritizing candidate genes for further experimentation. (I) The rich collection of genetic studies performed on Autism Genetic Resource Exchange (AGRE) families between 2001 and 2012 was mined to identify genome-wide significant linkage and association signals. (II) Markers were remapped to the current genome build (NCBI human genome build 36.3) and flanking regions extracted. (III) Single-nucleotide polymorphism (SNP) genotypes of AGRE male probands were compiled to enable male-specific genetic distance calculations in the same subjects. (IV) Regional recombination rates between markers and SNPs were calculated and (V) protein-coding genes within 20 male-specific cM from the markers identified. (VI) The expression profiles of these genes were examined in brain and blood of individuals with autism spectrum disorder (ASD) relative to neurotypical individuals. Genes found to be differentially expressed in both tissues and located within the male-specific vicinity of a significant autism marker are considered prime candidates for further studies. Of 30 genes that satisfy these criteria, 19 were previously implicated in disorders that share symptoms and morbidity patterns with ASD.

expression data with empty gene symbols, genes with very low absolute expression values and genes with low variance were removed from the preprocessed data set.

The GSE28521 data set consisted of postmortem brain tissue samples from 19 autism cases and 17 controls from the Autism Tissue Project, using the Illumina (San Diego, CA, USA) HumanRef-8 v3.0 expression beadchip panel. Three regions of the brain previously implicated in autism were profiled in each individual: superior temporal gyrus (also known as Brodmann's area 41/42), prefrontal cortex (BA9) and cerebellar vermis. Raw data were formatted with $\log _{2}$ transformation and normalized by quantile normalization. We considered probes with detection $P$-value $<0.05$ for at least half of the samples for further analysis, as described here. ${ }^{29}$ Raw $P$-values were generated using limma/bioconductor package in $\mathrm{R}$ software (http://www.bioconductor.org/ packages/2.12/bioc/html/limma.html), and Benjamini and Hochberg multiple testing correction was applied to obtain adjusted $P$-values.

Gene expression profiles around common autism markers. To examine the importance of genes at varying cM distances, and to examine the level of signal relevant to autism surrounding each autism marker individually, we treated each marker region as an independent hypothesis. We then examined the differential regulation of genes within LDS sets using the messenger RNA expression profiles described above. Our hypothesis is that genes at close genetic distances from autism markers will be more differentially regulated than genes not in LD with the autism markers.

Our tests for significant differential expression deviated from standard analyses of microarray data for the primary reason that each LDS set reflected independent, prior biological knowledge. As such, we treated each LDS set as a separate collection of hypotheses, with the number of hypotheses being tested simultaneously equivalent to the number of genes in the set. To appropriately account for this multiple testing, we adjusted the nominal $P$-values using the $q$-value calculation, ${ }^{31}$ a measurement framed in terms of the false discovery rate. ${ }^{32}$ All 67 LDS sets were investigated in this way to determine the frequencies of significant, adjusted $P$-values $(q<0.05)$ surrounding each autism marker.

Disease cross-referencing. We mined eight existing genedisease annotation resources for genes associated with neurological disorders considered to be closely related to autism. $^{33}$ Diseases included tuberous sclerosis, epilepsy, seizure disorder and many others with established behavioral similarities to ASD. The databases examined included the Genetic Association Database, ${ }^{34}$ Database of Genomic Variants (http://projects.tcag.ca/variation/), dbSNP (http:// www.ncbi.nlm.nih.gov/projects/SNP/), HuGE Navigator Navigator, ${ }^{35}$ Human Gene Mutation Database (http://www. hgmd.cf.ac.uk/ac/index.php), Online Mendelian Inheritance in Man (http://www.ncbi.nlm.nih.gov/omim/), GeneCards (http://www.genecards.org/) and SNPedia (http://snpedia. com/index.php/SNPedia). Results from these resources 
were integrated to create a list of genes and associated gene characteristics, which was used for comparisons with the autism LDS genes.

\section{Results}

More than 200 genetic studies were conducted on AGRE families between 2001 and 2012. These were mined to identify 67 genome-wide significant linkage and association signals for ASD (Table 1). Common markers for autism span 18 chromosomes, all with a logarithm-of-the-odds score $>3$ or a corrected association $P$-value $<0.01$. These studies were based on various experimental designs, mostly using multiplex families with affected sib-pairs. We calibrated the positions of significant markers using $\mathrm{NCBI}$ human genome build 36.3 (NCBI), and then aggregated all SNPs within a 10-MB window on either side of the marker to calculate the male-specific structure of LD around each marker. Examining the recombination rates in the same subjects allows us to build a population-specific genetic map, eliminating any genetic bias that might arise from considering ethnicity-matched controls.

Our calculations of recombination rates and LD between SNPs and common autism markers identified a total of 1426 genes within $25 \mathrm{cM}$ of the markers. Of those, 697 protein- coding genes were within $5 \mathrm{cM}, 450$ between 5 and $10 \mathrm{cM}$ and 212 between 10 and $15 \mathrm{cM}$ from the nearest autism locus (Figure 2). Both recombination rates and gene densities varied extensively among autism markers $(28.1 \pm 7.3 \mathrm{cM}$ in the $20-\mathrm{Mb}$ region around markers, spanning $35.4 \pm 10.4$ genes). There was a strong correlation ( $r$ o $=0.7)$ between the size of the genetic map and the proportion of genes at distances $>10 \mathrm{cM}$. The highest density of genes was around RFWD2 and PAPPA2 on chromosome 1, in a copy-number variation-associated region encoding 60 genes within $24 \mathrm{cM}$. Forty-eight and $90 \%$ of the genes fell within 5 and $10 \mathrm{cM}$, respectively, indicating that LD was well preserved with increasing distance from the autism locus. In contrast, the region around a common copy-number variations near UNQ3037 on chromosome 3 contained $73 \%$ genes at a distance greater than $>10 \mathrm{cM}$.

Previous results indicate that the information content varies by marker and genetic distance, but do not directly demonstrate whether this information is of relevance to our understanding of the genetic etiology of autism. To test directly whether specific markers and/or regions surrounding those markers are more likely to contain promising new gene leads, we examined the regulatory patterns of each LDS set independently in two expression data sets obtained from the

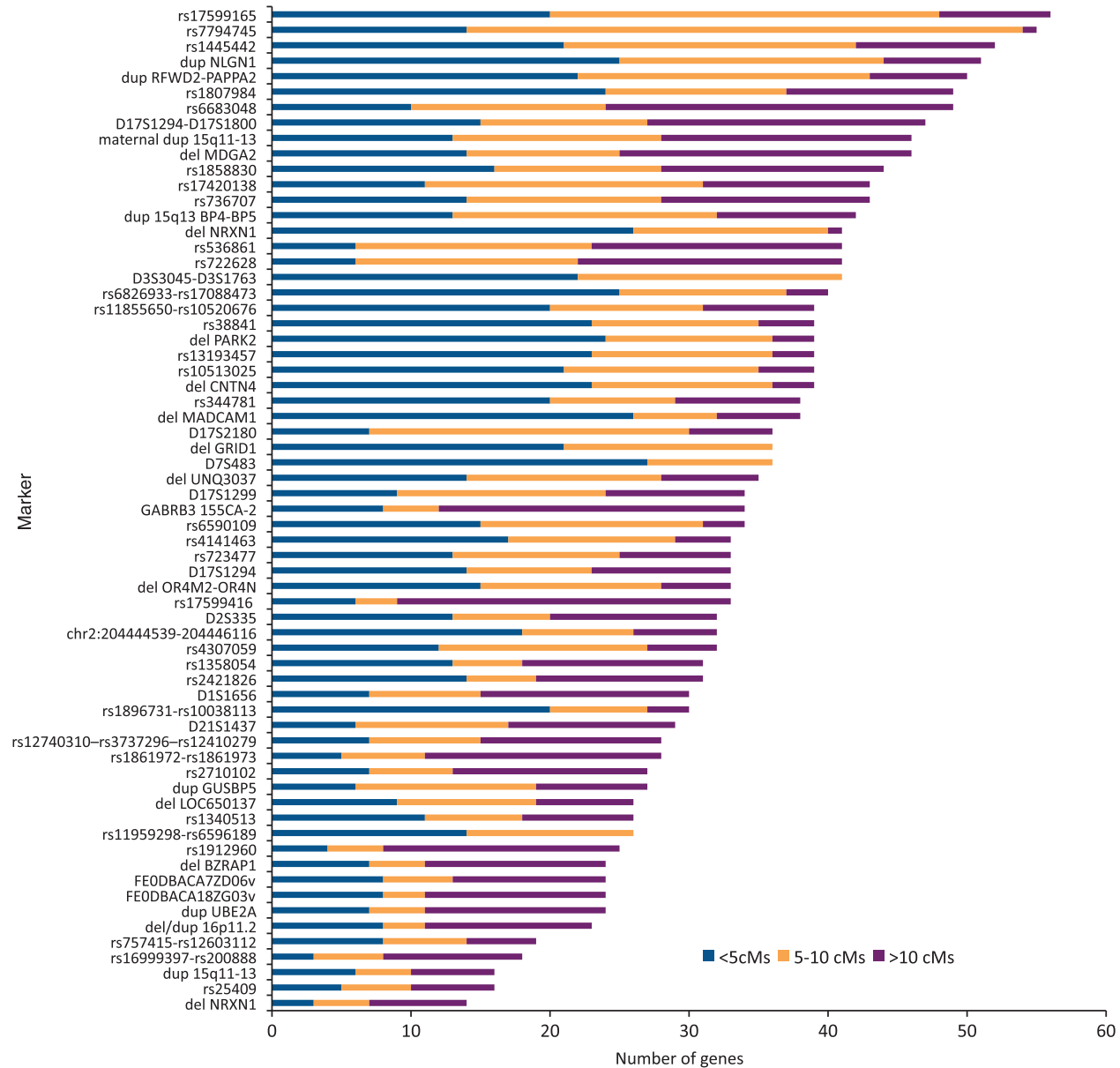

Figure 2 Number of genes within $20 \mathrm{cM}$ of significant autism markers. Genetic distances were calculated using male-only Autism Genetic Resource Exchange (AGRE) proband single-nucleotide polymorphisms (SNPs). ${ }^{11}$ Genes were grouped into three distance bins indicating the extent of recombination with the autism marker. The figure displays the number of genes in tight linkage with the marker, and therefore the extent of recombination around each locus. 
Gene Expression Omnibus: a blood-based messenger RNA expression data from individuals with autism and controls (GSE6575) $^{28}$ and a transcriptomic analysis of postmortem brain RNA (GSE28521). In the blood-based expression data set, although the large majority showed no change in

Table 2 Differential expression of genes around common autism markers

\begin{tabular}{|c|c|c|c|c|}
\hline \multirow[b]{2}{*}{ Marker } & \multicolumn{2}{|c|}{ Blood (GSE6575) } & \multicolumn{2}{|c|}{ Brain (GSE28521) } \\
\hline & $\begin{array}{l}\text { Number of } \\
\text { surrounding } \\
\text { genes with } \\
\text { expression } \\
\text { data }\end{array}$ & $\begin{array}{c}\% \text { of genes } \\
\text { significantly } \\
\text { differentially } \\
\text { expressed in } \\
\text { individuals } \\
\text { with ASD }\end{array}$ & $\begin{array}{l}\text { Number of } \\
\text { surrounding } \\
\text { genes with } \\
\text { expression } \\
\text { data }\end{array}$ & $\begin{array}{c}\% \text { of genes } \\
\text { significantly } \\
\text { differentially } \\
\text { expressed } \\
\text { in individuals } \\
\text { with } A S D\end{array}$ \\
\hline del CNTN4 & 16 & 100.0 & 12 & 100.0 \\
\hline rs10513025 & 12 & 75.0 & 12 & 100.0 \\
\hline D3S3045-D3S1763 & 22 & 50.0 & 26 & 100.0 \\
\hline (CNV: UNQ3037) & 19 & 89.5 & 21 & 66.7 \\
\hline rs11855650-rs10520676 & 21 & 28.6 & 18 & 100.0 \\
\hline del NRXN1 & 35 & 5.7 & 27 & 100.0 \\
\hline del NRXN1 (Bucan et al. ${ }^{41}$ ) & 32 & 6.3 & 24 & 100.0 \\
\hline rs6683048 & 43 & 4.7 & 30 & 100.0 \\
\hline dup AK123120 & 13 & 0.0 & 17 & 100.0 \\
\hline rs 4307059 & 16 & 0.0 & 7 & 100.0 \\
\hline rs1896731-rs10038113 & 15 & 0.0 & 7 & 100.0 \\
\hline rs7794745 & 37 & 0.0 & 23 & 100.0 \\
\hline rs2710102 & 38 & 0.0 & 25 & 100.0 \\
\hline rs736707 & 30 & 0.0 & 23 & 100.0 \\
\hline rs344781 & 28 & 0.0 & 16 & 100.0 \\
\hline D7S483 & 29 & 0.0 & 21 & 95.2 \\
\hline rs1861972-rs1861973 & 27 & 0.0 & 19 & 94.7 \\
\hline del GRID1 & 28 & 14.3 & 17 & 94.1 \\
\hline del BZRAP1 & 19 & 0.0 & 14 & 92.9 \\
\hline rs17599165 & 24 & 0.0 & 13 & 84.6 \\
\hline rs1912960 & 24 & 0.0 & 13 & 84.6 \\
\hline rs17599416 & 24 & 0.0 & 13 & 84.6 \\
\hline rs757415-rs12603112 & 25 & 4.0 & 22 & 81.8 \\
\hline dup NLGN1 & 22 & 0.0 & 16 & 81.3 \\
\hline D17S2180 & 27 & 0.0 & 21 & 76.2 \\
\hline $\begin{array}{l}\text { Chr2:204444539-204446116 } \\
\text { LD block }\end{array}$ & 25 & 36.0 & 10 & 70.0 \\
\hline rs1807984 & 25 & 0.0 & 20 & 70.0 \\
\hline D1S1656 & 42 & 0.0 & 36 & 66.7 \\
\hline del MDGA2 & 17 & 0.0 & 11 & 63.6 \\
\hline FE0DBACA18ZG03v & 30 & 0.0 & 22 & 63.6 \\
\hline $\begin{array}{l}\text { rs12740310-rs3737296- } \\
\text { rs12410279 }\end{array}$ & 28 & 0.0 & 21 & 61.9 \\
\hline D2S335 & 28 & 0.0 & 18 & 61.1 \\
\hline rs4519482 & 28 & 0.0 & 18 & 61.1 \\
\hline FE0DBACA7ZD06v & 24 & 0.0 & 18 & 61.1 \\
\hline rs38841 & 22 & 9.1 & 23 & 60.9 \\
\hline rs1858830 & 22 & 9.1 & 23 & 60.9 \\
\hline dup GUSBP5 & 17 & 0.0 & 12 & 58.3 \\
\hline rs 723477 & 9 & 11.1 & 16 & 56.3 \\
\hline del PARK2 & 35 & 11.4 & 20 & 50.0 \\
\hline dup RFWD2-PAPPA2 & 32 & 0.0 & 24 & 50.0 \\
\hline rs6826933-rs17088473 & 12 & 0.0 & 10 & 50.0 \\
\hline rs16999397-rs200888 & 13 & 0.0 & 18 & 50.0 \\
\hline dup UBE2A & 14 & 7.1 & 13 & 46.2 \\
\hline maternal dup 15q11-13 & 15 & 6.7 & 13 & 46.2 \\
\hline GABRB3 155CA-2 & 15 & 6.7 & 13 & 46.2 \\
\hline rs25409 & 15 & 6.7 & 13 & 46.2 \\
\hline dup $15 q 11-13$ & 15 & 6.7 & 13 & 46.2 \\
\hline rs4141463 & 10 & 20.0 & 18 & 44.4 \\
\hline D21S1437 & 10 & 0.0 & 7 & 42.9 \\
\hline $\mathrm{del} / \mathrm{dup} 16 \mathrm{p} 11.2$ & 15 & 0.0 & 12 & 41.7 \\
\hline dup 15q13 BP4-BP5 & 23 & 8.7 & 19 & 31.6 \\
\hline rs11959298-rs6596189 & 23 & 0.0 & 16 & 31.3 \\
\hline rs1358054 & 29 & 31.0 & 26 & 30.8 \\
\hline rs1340513 & 24 & 0.0 & 13 & 30.8 \\
\hline rs722628 & 24 & 0.0 & 13 & 30.8 \\
\hline D17S1299 & 20 & 0.0 & 20 & 30.0 \\
\hline rs536861 & 33 & 0.0 & 25 & 28.0 \\
\hline del OR4M2-OR4N & 10 & 10.0 & 11 & 27.3 \\
\hline del LOC650137 & 10 & 10.0 & 11 & 27.3 \\
\hline rs2421826 & 26 & 46.2 & 23 & 26.1 \\
\hline D17S1294-D17S1800 & 21 & 0.0 & 17 & 17.6 \\
\hline D17S1294 & 21 & 0.0 & 17 & 17.6 \\
\hline rs6590109 & 24 & 0.0 & 18 & 11.1 \\
\hline rs13193457 & 27 & 0.0 & 21 & 9.5 \\
\hline rs17420138 & 17 & 100.0 & 17 & 0.0 \\
\hline rs 1445442 & 24 & 0.0 & 0 & 0.0 \\
\hline del MADCAM1 & 8 & 0.0 & 5 & 0.0 \\
\hline
\end{tabular}

Abbreviations: ASD, autism spectrum disorder; CNV, copy-number variation. For each marker region, the table lists the percentage of genes found to be differentially expressed in blood and brain of individuals with ASD at a significance level of $q<0.05$. expression, 27 marker regions (40\%) contained at least one gene with significant, multiple test-corrected differential expression (Table 2). More than $50 \%$ of the genes around markers on 3p26 (del CNTN4, del UNQ3037), 3q (D3S3045D3S1763), 2q (rs17420138) and 5p (rs10513025) were differentially expressed in whole blood from individuals with ASD. In all, 79 genes were significantly enriched at $q<0.05$ across all the marker sets out of which 31 (39\%) and 60 (76\%) genes lie within 5 and $10 \mathrm{cM}$ of the nearest autism marker, respectively, further supporting the notion that the genes proximal to the markers represent more viable autism gene leads than genes further away.

In postmortem brain tissue data there was an abundance of signal in 64 of the 67 LDS sets, which contained at least one gene at $q$-value $<0.05$. Regions around 41 markers contained gene sets with significant differential expression, defined as $>50 \%$ of gene differentially expressed in at least one brain region between individuals with $A S D$ and matched controls at a $q$-value threshold of 0.05 . Of 383 genes showing evidence of differential expression at $q<0.05,205$ (53\%) and 323 (84\%) lie within 5 and $10 \mathrm{cM}$ of the nearest autism marker, respectively.

Four markers were found to reside within a neighborhood of differentially expressed genes in both brain and blood of individuals with ASD. At least $50 \%$ of protein-coding genes around rs10513025, D3S3045-D3S1763, del CNTN4 and del UNQ3037 are differentially expressed in both tissues (Table 2). Three of these regions, $20 \mathrm{Mb}$ around del CNTN4, del UNQ3037 and rs10513025 show heavy recombination and contain $73 \%, 68 \%$ and $47 \%$ of genes, respectively, at $>10 \mathrm{cM}$. Despite significant recombination within the region, genes significantly enriched for differential expression in both data sets were those closer to the autism marker. Of 30 genes found to be significantly differentially expressed in both blood and brain of individuals with ASD, 11 and 20 were within 5 and $10 \mathrm{cM}$ of the nearest autism marker, respectively.

Integrating a decade of genome-wide linkage and association studies, the male bias of ASD and differential expression in both brain and blood of individuals with ASD has identified a set of 30 prime candidates for future experimentation, such as efficient targeted resequencing in very large cohorts. ${ }^{36}$ Of these, CADPS2, CNTN4, NTRK3, SLC9A9 and SUMF1 have been previously implicated in ASD. Other differentially expressed genes within 20 male-specific cM of common autism markers have been implicated in disorders with shared symptoms and morbidity patterns, but have not yet been implicated in ASD (Table 3).

\section{Discussion}

Despite the high heritability of autism, efforts to identify its genetic causes have enjoyed only limited success. Numerous susceptibility loci have been identified, yet few have been replicated, supporting the notion that the genetic complexity of this disorder outmatches the proportion of the population with autism that has been sampled to date. Until the sampling adequately covers the diversity of genetic systems underlying ASD, we must develop analytical approaches to make optimal use of existing results. To this end, we focused here on 
Table 3 Top candidate genes based on integrating a decade of genome-wide linkage and association studies, the autism male bias and differential expression in brain and blood of individuals with autism spectrum disorder (ASD)

\begin{tabular}{|c|c|c|c|c|c|c|}
\hline \multirow[b]{2}{*}{ Gene } & \multicolumn{2}{|c|}{ Differential expression in blood } & \multicolumn{2}{|c|}{ Differential expression in brain } & \multirow{2}{*}{$\begin{array}{c}\text { Male-specific genetic } \\
\text { distance from marker (cM) }\end{array}$} & \multirow{2}{*}{$\begin{array}{c}\text { Association with disorders } \\
\text { comorbid to } A S D^{\mathrm{a}}\end{array}$} \\
\hline & $\mathrm{t}$-test $\mathrm{P}$ & $F D R$ & t-test $\mathrm{P}$ & $F D R$ & & \\
\hline TRIM44 & $9.5 e-02$ & $4.8 e-02$ & $5.1 e-03$ & $1.4 e-02$ & 0.84 & \\
\hline ITPR1 & $7.7 e-01$ & $9.3 e-04$ & $1.9 e-03$ & $1.5 e-03$ & 1.09 & $4,7,15,16$ \\
\hline IREB2 & $2.3 e-02$ & $4.0 e-02$ & $1.2 e-02$ & $2.8 e-03$ & 1.39 & 4,10 \\
\hline CNTN4 & $1.4 e-01$ & $2.4 e-02$ & $3.2 e-01$ & $5.1 e-03$ & 1.88 & $4,6,8,16,18,19$ \\
\hline NMNAT3 & $2.0 e-01$ & $4.5 e-02$ & $4.6 e-01$ & $8.3 e-03$ & 2.39 & 10 \\
\hline$R A B 6 B$ & $2.0 e-01$ & $4.5 e-02$ & $1.0 e-03$ & $1.9 e-04$ & 3.02 & \\
\hline CADPS2 & $4.1 e-04$ & $3.7 e-03$ & $1.0 e-05$ & $4.9 e-05$ & 3.34 & 5,6 \\
\hline SPTBN1 & $1.5 e-03$ & $9.1 e-03$ & $1.6 e-01$ & $3.1 e-06$ & 3.56 & 1,16 \\
\hline TMEM108 & $2.1 e-01$ & $4.5 e-02$ & $1.0 e-01$ & $2.8 e-03$ & 4.09 & \\
\hline ACPL2 & $8.3 e-02$ & $2.8 e-02$ & $8.2 e-02$ & $2.4 \mathrm{e}-03$ & 4.43 & \\
\hline$A D C Y 2$ & $1.4 e-01$ & $3.2 e-02$ & $3.9 e-02$ & $3.9 e-03$ & 4.77 & 16 \\
\hline NSUN2 & $1.1 e-02$ & $1.1 e-02$ & $7.7 e-01$ & $3.8 e-02$ & 6.62 & 16 \\
\hline PANK1 & $1.4 e-02$ & $3.8 e-02$ & $7.7 e-03$ & $2.8 e-03$ & 7.14 & \\
\hline SUMF1 & $1.4 e-01$ & $2.4 e-02$ & $4.9 e-01$ & $6.7 e-03$ & 7.31 & $9,10,13,21,22$ \\
\hline TANC1 & $1.2 e-01$ & $1.7 e-03$ & $6.0 e-02$ & $3.8 e-02$ & 7.31 & $4,6,17,19,20$ \\
\hline SLC23A2 & $1.6 e-02$ & $2.7 e-02$ & $2.4 e-02$ & $1.8 e-02$ & 8.35 & \\
\hline EPB41L5 & $2.5 e-03$ & $1.3 e-02$ & $3.5 e-02$ & $1.8 e-02$ & 8.65 & \\
\hline ALKBH3 & $1.6 e-01$ & $3.7 e-02$ & $3.0 e-05$ & $2.4 \mathrm{e}-04$ & 9.00 & \\
\hline SLC9A9 & $7.5 e-02$ & $2.8 e-02$ & $4.3 e-04$ & $1.8 e-04$ & 9.04 & $5,6,8,15,18,20$ \\
\hline NTRK3 & $3.0 e-02$ & $4.0 e-02$ & $7.9 e-02$ & $9.1 e-03$ & 9.67 & $2,3,5,6,7,11,15,16,17,23$ \\
\hline PLSCR4 & $5.4 e-02$ & $2.8 e-02$ & $8.4 e-03$ & $5.0 e-04$ & 12.30 & 7,16 \\
\hline MYO10 & $1.4 e-01$ & $3.2 e-02$ & $1.4 e-01$ & $9.2 e-03$ & 12.64 & 10 \\
\hline KCNMA1 & $1.3 e-02$ & $3.8 e-02$ & $2.4 e-01$ & $2.2 e-02$ & 13.86 & $2,8,10,15,16,18$ \\
\hline SMYD3 & $4.8 e-04$ & $9.5 e-03$ & $2.6 e-02$ & $1.8 e-03$ & 14.32 & \\
\hline ATP2B2 & $5.3 e-02$ & $2.4 e-02$ & $1.1 e-03$ & $9.4 e-04$ & 14.77 & $14,16,20$ \\
\hline ALDH18A1 & $9.1 e-03$ & $3.8 e-02$ & $6.0 e-01$ & $4.1 e-02$ & 15.93 & $8,10,12,18,19,20$ \\
\hline LMCD1 & $1.3 e-01$ & $2.4 \mathrm{e}-02$ & $5.4 e-01$ & $6.7 e-03$ & 16.72 & \\
\hline ATG7 & $2.7 e-01$ & $4.5 e-04$ & $3.4 \mathrm{e}-04$ & $7.1 e-04$ & $16.7 \overline{8}$ & 10 \\
\hline SYN2 & $2.6 e-01$ & $2.6 e-02$ & $4.6 e-03$ & $2.9 e-03$ & 18.41 & $7,8,15,16$ \\
\hline MKRN2 & $2.3 e-01$ & $2.6 e-02$ & $2.0 e-02$ & $9.5 e-03$ & 18.70 & \\
\hline
\end{tabular}

Abbreviation: FDR, false discovery rate.

Listed are genes located within 20 male-specific cM of genome-wide significant autism markers, which are also differentially expressed in both brain and blood of individuals with ASD. Of these, 19 genes (63\%) were previously implicated in neurological disorders with high degrees of overlap in symptomatology and morbidity to ASD.

aList of disorders: (1) neurofibromatosis, (2) tuberous sclerosis, (3) anxiety disorders, (4) ataxia, (5) attention deficit disorder, (6) autistic disorder, (7) bipolar disorder, (8) seizures, (9) cerebral palsy, (10) dementia, (11) depressive disorder, (12) Down syndrome, (13) dystonia, (14) encephalomyelitis, (15) epilepsy, (16) schizophrenia, (17) hydrocephalus, (18) mental retardation, (19) microcephaly, (20) multiple sclerosis, (21) neuroacanthocytosis, (22) neuroaxonal dystrophies, (23) obsessive-compulsive disorder.

the development of a simple strategy aimed at targeting previously published autism markers, as well as genes genetically proximal to those markers and most likely to be causally related to ASD. By coupling the structure of LD with knowledge of biological process and patterns of gene expression data from individuals with ASD, we were able to identify a set of markers and genes proximal to those markers likely to be most informative to the genetic basis of autism. Specific loci on a few chromosomes including three signals on chromosome 3 and one on chromosome 5 yielded the greatest signal, with a sizable percentage of adjacent genes showing highly significant differential expression in blood and brain data from individuals with autism. In support of their relevance to the genetics of autism, many of the differentially expressed genes closely linked to the markers have already been identified as promising autism gene candidates, such as CNTN4, CADPS2, SUMF1, NTRK3 and SLC9A9. In addition, an even greater percentage of these genes have been linked to neurological diseases with high comorbidity and behavioral similarities to ASD.
Overall, our strategy provides a means for meta-analysis of previous linkage and association studies to prioritize both markers and adjacent genes for further experimental analysis. Although our results corroborate the general rule of thumb that genes close to loci identified via linkage and association studies are likely to be informative to the disease under study, they stress that this rule only applies to specific markers. Given the success of application to the autism research field, we expect that our analytical strategy could be of general use in the study of other similarly complex genetic diseases, such as Alzheimer's disease and type 1 diabetes.

\section{Conflict of interest}

The authors declare no conflict of interest.

Acknowledgements. We would like to thank Autism Speaks, AGRE, and participating families for making the data for this research available. We thank Wall lab members and Professors Isaac Kohane, Marco Ramoni and Peter Tonellato for engaging discussions related to the project. This work was supported by the 
National Institute of Health Grants 1R01MH085143-01 and 1R01MH090611-01A1 awared to DPW.

1. Autism and Developmental Disabilities Monitoring Network Surveillance Year 2008 Principal Investigators, Centers for Disease Control and Prevention. Prevalence of autism spectrum disorders-Autism and Developmental Disabilities Monitoring Network, 14 sites, United States, 2008. MMWR Surveill Summ 2012; 61: 1-19.

2. Bailey A, Le Couteur A, Gottesman I, Bolton P, Simonoff E, Yuzda E et al. Autism as a strongly genetic disorder: evidence from a British twin study. Psychol Med 1995; 25: 63-77.

3. Lauritsen M., Ewald H. The genetics of autism. Acta Psychiatr Scand 2001; 103: 411-427.

4. Rutter M. Genetic studies of autism: from the 1970s into the millennium. J Abnorm Child Psychol 2000; 28: 3-14.

5. Ronald A, Hoekstra R. A. Autism spectrum disorders and autistic traits: a decade of new twin studies. Am J Med Genet B Neuropsychiatr Genet 2011; 156B: 255-274.

6. Hallmayer J, Cleveland S, Torres A, Phillips J, Cohen B, Torigoe T et al. Genetic heritability and shared environmental factors among twin pairs with autism. Arch Gen Psychiatry 2011; 68: 1095-1102.

7. Sanders SJ, Murtha MT, Gupta AR, Murdoch JD, Raubeson MJ, Willsey AJ et al. De novo mutations revealed by whole-exome sequencing are strongly associated with autism. Nature 2012; 485: 237-241.

8. Neale BM, Kou Y, Liu L, Ma'ayan A, Samocha KE, Sabo A et al. Patterns and rates of exonic de novo mutations in autism spectrum disorders. Nature 2012; 485: 242-245.

9. O'Roak BJ, Vives L, Girirajan S, Karakoc E, Krumm N, Coe BP et al. Sporadic autism exomes reveal a highly interconnected protein network of de novo mutations. Nature 2012 485: $246-250$.

10. Iossifov I, Ronemus M, Levy D, Wang Z, Hakker I, Rosenbaum J et al. De novo gene disruptions in children on the autistic spectrum. Neuron 2012; 74: 285-299.

11. Wang K, Zhang H, Ma D, Bucan M, Glessner JT, Abrahams BS et al. Common genetic variants on 5p14.1 associate with autism spectrum disorders. Nature 2009; 459: 528-533.

12. Zhao X, Leotta A, Kustanovich V, Lajonchere C, Geschwind DH, Law K et al. A unified genetic theory for sporadic and inherited autism. Proc Natl Acad Sci USA 2007; 104 12831-12836.

13. Sebat J, Lakshmi B, Malhotra D, Troge J, Lese-Martin C, Walsh T et al. Strong association of de novo copy number mutations with autism. Science 2007; 316: 445-449.

14. Morrow EM, Yoo SY, Flavell SW, Kim TK, Lin Y, Hill RS et al. Identifying autism loci and genes by tracing recent shared ancestry. Science 2008; 321: 218-223.

15. Szatmari $P$, Paterson AD, Zwaigenbaum L, Roberts W, Brian J, Liu XQ et al. Mapping autism risk loci using genetic linkage and chromosomal rearrangements. Nat Genet 2007; 39: 319-328.

16. Abrahams BS, Geschwind DH. Advances in autism genetics: on the threshold of a new neurobiology. Nat Rev Genet 2008; 9: 341-355.

17. Freitag $\mathrm{CM}$. The genetics of autistic disorders and its clinical relevance: a review of the literature. Mol Psychiatry 2007; 12: 2-22.

18. Alarcon M, Yonan AL, Gilliam TC, Cantor RM, Geschwind DH. Quantitative genome scan and Ordered-Subsets Analysis of autism endophenotypes support language QTLs. Mol Psychiatry 2005; 10: 747-757.

19. Cantor R M, Kono N, Duvall JA, Alvarez-Retuerto A, Stone JL, Alarcon M et al. Replication of autism linkage: fine-mapping peak at 17q21. Am J Hum Genet 2005; 76: 1050-1056.

20. McCauley JL, Li C, Jiang L, Olson LM, Crockett G, Gainer K et al. Genome-wide and Ordered-Subset linkage analyses provide support for autism loci on $17 q$ and $19 p$ with evidence of phenotypic and interlocus genetic correlates. BMC Med Genet 2005; 6: 1.

21. Yonan AL, Alarcon M, Cheng R, Magnusson PK, Spence SJ, Palmer AA et al. A genomewide screen of 345 families for autism-susceptibility loci. Am J Hum Genet 2003 73: $886-897$.

22. Bailey A, Hervas A, Matthews N, Palferman S, Wallace S, Aubin A. A full genome screen for autism with evidence for linkage to a region on chromosome 7q. International Molecular Genetic Study of Autism Consortium. Hum Mol Genet 1998; 7: 571-578.

23. International Molecular Genetic Study of Autism Consortium (IMGSAC). A genomewide screen for autism: strong evidence for linkage to chromosomes 2q, 7q, and 16p. Am J Hum Genet 2001; 69: 570-581.

24. International Molecular Genetic Study of Autism Consortium (IMGSAC). Further characterization of the autism susceptibility locus AUTS1 on chromosome 7q. Hum Mol Genet 2001; 10: 973-982.

25. Alarcon M, Cantor RM, Liu J, Gilliam TC, Geschwind DH. Evidence for a language quantitative trait locus on chromosome $7 q$ in multiplex autism families. Am J Hum Genet 2002; 70: 60-71.

26. Barrett S, Beck JC, Bernier R, Bisson E, Braun TA, Casavant TL et al. An autosomal genomic screen for autism. Collaborative linkage study of autism. Am J Med Genet 1999; 88: 609-615.

27. McVean GA, Myers SR, Hunt S, Deloukas P, Bentley DR, Donnelly P. The fine-scale structure of recombination rate variation in the human genome. Science 2004; 304: 581-584.

28. Gregg JP, Lit L, Baron CA, Hertz-Picciotto I, Walker W, Davis RA et al. Gene expression changes in children with autism. Genomics 2008; 91: 22-29.

29. Voineagu I, Wang X, Johnston P, Lowe JK, Tian Y, Horvath S et al. Transcriptomic analysis of autistic brain reveals convergent molecular pathology. Nature 2011; 474: 380-384.
30. Wu Z, Irizarry RA, Gentleman R, Murillo FM, Spencer F. A model based background adjustment for oligonucleotide expression arrays. J Amer Stat Assoc 2004 99: 909-917.

31. Storey JD, Tibshirani R. Statistical significance for genomewide studies. Proc Natl Acad Sci USA 2003; 100: 9440-9445.

32. Benjamini $Y$, Hochberg $Y$. Controlling the false discovery rate: a practical and powerful approach to multiple testing. J Roy Statist Soc Ser B 1995; 57: 289-300.

33. Wall DP, Esteban FJ, Deluca TF, Huyck M, Monaghan T, Velez de Mendizabal N et al. Comparative analysis of neurological disorders focuses genome-wide search for autism genes. Genomics 2009; 93: 120-129.

34. Becker KG, Barnes KC, Bright TJ, Wang SA. The genetic association database. Nat Genet 2004; 36: 431-432.

35. Yu W, Gwinn M, Clyne M, Yesupriya A, Khoury MJ. A navigator for human genome epidemiology. Nat Genet 2008; 40: 124-125

36. O'Roak BJ, Vives L, Fu W, Egertson JD, Stanaway IB, Phelps IG et al. Multiplex targeted sequencing identifies recurrently mutated genes in autism spectrum disorders. Science 2012; 338: 1619-1622.

37. Glessner JT, Wang K, Cai G, Korvatska O, Kim CE, Wood S et al. Autism genome-wide copy number variation reveals ubiquitin and neuronal genes. Nature 2009; 459 569-573.

38. Ma D, Salyakina D, Jaworski JM, Konidari I, Whitehead PL, Andersen AN et al. A genomewide association study of autism reveals a common novel risk locus at 5p14.1. Ann Hum Genet 2009; 73: 263-273.

39. Buxbaum JD, Silverman J, Keddache M, Smith CJ, Hollander E, Ramoz N et al. Linkage analysis for autism in a subset families with obsessive-compulsive behaviors: evidence fo an autism susceptibility gene on chromosome 1 and further support for susceptibility genes on chromosome 6 and 19. Mol Psychiatry 2004; 9: 144-150.

40. Lu AT, Cantor RM. Allowing for sex differences increases power in a GWAS of multiplex autism families. Mol Psychiatry 2012; 17: 215-222.

41. Bucan M, Abrahams BS, Wang K, Glessner JT, Herman El, Sonnenblick LI et al. Genomewide analyses of exonic copy number variants in a family-based study point to novel autism susceptibility genes. PLoS Genet 2009; 5: e1000536.

42. Ramoz N, Cai G, Reichert JG, Silverman JM, Buxbaum JD. An analysis of candidate autism loci on chromosome 2q24-q33: evidence for association to the STK39 gene. Am J Med Genet B Neuropsychiatr Genet 2008; 147B: 1152-1158.

43. Buxbaum JD, Silverman JM, Smith CJ, Kilifarski M, Reichert J, Hollander E et al. Evidence for a susceptibility gene for autism on chromosome 2 and for genetic heterogeneity. Am J Hum Genet 2001; 68: 1514-1520.

44. Liu X, Novosedlik N, Wang A, Hudson ML, Cohen IL, Chudley AE et al. The DLX1and DLX2 genes and susceptibility to autism spectrum disorders. Eur J Hum Genet 2009; 17 228-235.

45. Hussman JP, Chung RH, Griswold AJ, Jaworski JM, Salyakina D, Ma D et al. A noisereduction GWAS analysis implicates altered regulation of neurite outgrowth and guidance in autism. Mol Autism 2011; 2: 1 .

46. Collins AL, Ma D, Whitehead PL, Martin ER, Wright HH, Abramson RK et al. Investigation of autism and GABA receptor subunit genes in multiple ethnic groups. Neurogenetics 2006 7: 167-174.

47. Fradin D, Cheslack-Postava K, Ladd-Acosta C, Newschaffer C, Chakravarti A, Arking D. E. et al. Parent-of-origin effects in autism identified through genome-wide linkage analysis of 16,000 SNPs. PLoS One 2010; 5: e12513.

48. Weiss LA, Arking DE, Daly MJ, Chakravarti A. Gene Discovery Project of Johns, H., the Autism, C. A genome-wide linkage and association scan reveals novel loci for autism. Nature 2009; 461: 802-808.

49. Philippi A, Tores F, Carayol J, Rousseau F, Letexier M, Roschmann E et al. Association of autism with polymorphisms in the paired-like homeodomain transcription factor 1 (PITX1) on chromosome 5q31: a candidate gene analysis. BMC Med Genet 2007 8: 74

50. Bureau A, Croteau J, Tayeb A, Merette C, Labbe A. Latent class model with familia dependence to address heterogeneity in complex diseases: adapting the approach to family-based association studies. Genet Epidemiol 2011; 35: 182-189.

51. Serajee FJ, Zhong H, Mahbubul Huq AH. Association of Reelin gene polymorphisms with autism. Genomics 2006; 87: 75-83.

52. Campbell DB, Sutcliffe JS, Ebert PJ, Militerni R, Bravaccio C, Trillo $S$ et al. A genetic variant that disrupts MET transcription is associated with autism. Proc Natl Acad Sci USA 2006 103: 16834-16839.

53. Thanseem I, Nakamura K, Miyachi T, Toyota T, Yamada S, Tsuiji M et al. Further evidence for the role of MET in autism susceptibility. Neurosci Res 2010; 68: 137-141.

54. Arking DE, Cutler DJ, Brune CW, Teslovich TM, West $\mathrm{K}$, lkeda $\mathrm{M}$ et al. A common genetic variant in the neurexin superfamily member CNTNAP2 increases familial risk of autism. Am J Hum Genet 2008; 82: 160-164.

55. Alarcon M, Abrahams BS, Stone JL, Duvall JA, Perederiy JV, Bomar JM et al. Linkage, association, and gene-expression analyses identify CNTNAP2 as an autism-susceptibility gene. Am J Hum Genet 2008; 82: 150-159.

56. Molloy CA, Keddache M, Martin LJ. Evidence for linkage on $21 \mathrm{q}$ and $7 \mathrm{q}$ in a subset of autism characterized by developmental regression. Mol Psychiatry 2005; 10 $741-746$. 
57. Benayed R, Gharani N, Rossman I, Mancuso V, Lazar G, Kamdar S et al. Support for the homeobox transcription factor gene ENGRAILED 2 as an autism spectrum disorder susceptibility locus. Am J Hum Genet 2005; 77: 851-868.

58. Szatmari P, Paterson AD, Zwaigenbaum L, Roberts W, Brian J, Meyer KJ. Autism Genome Project, C. Mapping autism risk loci using genetic linkage and chromosomal rearrangements. Nat Genet 2007; 39: 319-328.

59. Anitha A, Nakamura K, Yamada K, Suda S, Thanseem I, Tsujii M et al. Genetic analyses of roundabout (ROBO) axon guidance receptors in autism. Am J Med Genet B Neuropsychiatr Genet 2008; 147B: 1019-1027.

60. Ma DQ, Cuccaro ML, Jaworski JM, Haynes CS, Stephan DA, Parod J et al. Dissecting the locus heterogeneity of autism: significant linkage to chromosome 12q14. Mol Psychiatry 2007; 12: 376-384.

61. Weiss LA, Shen Y, Korn JM, Arking DE, Miller DT, Fossdal R et al. Association between microdeletion and microduplication at 16p11.2 and autism. N Engl J Med 2008; 358: 667-675.

62. Buxbaum JD, Silverman JM, Smith CJ, Greenberg DA, Kilifarski M, Reichert $\mathrm{J}$ et al. Association between a GABRB3 polymorphism and autism. Mol Psychiatry2002: 7: 311-316.

63. Delahanty RJ, Kang JQ, Brune CW, Kistner EO, Courchesne E, Cox NJ et al. Maternal transmission of a rare GABRB3 signal peptide variant is associated with autism. $\mathrm{Mol}$ Psychiatry 2011; 16: 86-96

64. Miller DT, Shen Y, Weiss LA, Korn J, Anselm I, Bridgemohan C et al. Microdeletion duplication at 15q13.2q13.3 among individuals with features of autism and other neuropsychiatric disorders. J Med Genet 2009; 46: 242-248.

65. Philippi A, Roschmann E, Tores F, Lindenbaum P, Benajou A, Germain-Leclerc $L$ et al. Haplotypes in the gene encoding protein kinase c-beta (PRKCB1) on chromosome 16 are associated with autism. Mol Psychiatry 2005; 10: 950-960.
66. Kumar RA, KaraMohamed S, Sudi J, Conrad DF, Brune C, Badner JA et al. Recurrent 16p11.2 microdeletions in autism. Hum Mol Genet 2008; 17: 628-638.

67. Sutcliffe JS, Delahanty RJ, Prasad HC, McCauley JL, Han Q, Jiang L et al. Allelic heterogeneity at the serotonin transporter locus (SLC6A4) confers susceptibility to autism and rigid-compulsive behaviors. Am J Hum Genet 2005; 77: 265-279.

68. Stone JL, Merriman B, Cantor RM, Yonan AL, Gilliam TC, Geschwind DH et al. Evidence for sex-specific risk alleles in autism spectrum disorder. Am J Hum Genet 2004; 75: 1117-1123.

69. Strom SP, Stone JL, Ten Bosch JR, Merriman B, Cantor RM, Geschwind DH et al. High-density SNP association study of the 17q21 chromosomal region linked to autism identifies CACNA1G as a novel candidate gene. Mol Psychiatry 2010; 15: 996-1005.

70. Campbell DB, Li C, Sutcliffe JS, Persico AM, Levitt P. Genetic evidence implicating multiple genes in the MET receptor tyrosine kinase pathway in autism spectrum disorder. Autism Res 2008; 1: 159-168.

71. Anney R, Klei L, Pinto D, Regan R, Conroy J, Magalhaes TR et al. A genome-wide scan for common alleles affecting risk for autism. Hum Mol Genet 2010; 19: 4072-4082.

cc) (i) $(\Theta)$ Translational Psychiatry is an open-access journal published by Nature Publishing Group. This work is licensed under a Creative Commons Attribution-NonCommercialNoDerivs 3.0 Unported License. To view a copy of this license, visit http://creativecommons.org/licenses/by-nc-nd/3.0/ 